\title{
Knowledge of Solar Energy Technology by the Farmers of Jaipur District in Rajasthan, India
}

\author{
Neelesh Raghuwanshi, Jagdish Prasad Yadav, Ajit Kumar Ghoslya*, \\ Vikas Kumar and Sita Ram Bijarnia
}

Department of Extension Education, SKNAU, Jobner, India

*Corresponding author

\begin{abstract}
A B S T R A C T
Keywords

Solar energy,

knowledge,

technology

Article Info

Accepted:

05 February 2020

Available Online:

10 March 2020

Solar energy technology is very important tool which can lowers worldwide carbon emissions. The present study was conducted in Jaipur district of Rajasthan. There are total sixteen tehsils in Jaipur district of Rajasthan, out of which, two tehsils namely Chomu and Amber were selected on the basis of maximum number of installed of solar pump. Ten villages from each selected tehsils were selected randomly by using proportional allocation technique. One hundred twenty (120) farmers were selected from twenty selected village by using proportional allocation technique. The study clearly showed that that majority of solar pump users (70.83 per cent) belonged to middle level of knowledge, followed by high level of knowledge (15.83 per cent). Whereas only13.34 per cent solar pump user were belonged to the low level of knowledge, respectively.
\end{abstract}

\section{Introduction}

Agriculture requires energy as an important input to production. Agriculture uses energy directly as fuel or electricity to operate machinery and equipment, to heat or cool buildings and for lighting on the farm and indirectly in the fertilizers and chemicals produced off the farm. Up to the industrial revolution (18th century), energy use relied only on muscular and biomass sources. Most work was provided by manual labor and animals while the biomass (mainly firewood) provided for heating and cooking energy needs. Other sources of energy such as windmills and water mills were present but their overall contribution was marginal and for very specific purposes (e.g. milling flour).

By the mid of the $19^{\text {th }}$ century, the industrial revolution brought a major shift in energy sources with the usage of coal, mainly for steam engines, but increasingly for power plants. As the $20^{\text {th }}$ century began, the major reliance was on coal but a gradual shift towards higher energy content sources like oil 
began. This second major shift saw the introduction of internal combustion engines and of oil-powered ships. In the late $20^{\text {th }}$ century, preeminence of petroleum products as the main provider of energy reached a high level of dependence in the world economy. As the level of technical expertise increased, more efficient sources of fossil fuels were tapped such as natural gas and an entirely new form of energy, nuclear fission, became available.

Renewable sources of energy, such as hydroelectric, wind and solar started to be tapped but remained marginal sources. The $21^{\text {st }}$ century will be characterized by major shifts in energy sources with a gradual obsolescence of fossil fuels like coal and oil for more efficient fossil fuels such as natural gas. There may also be a 'clean coal' technology potential (the term is more of an oxymoron).

Advances in biotechnologies, underline the growing potential of biomass derived fuels while wind and solar energy will also account for a notable share of energy sources. Nuclear energy, particularly if nuclear fusion becomes commercially possible, may also play a significant role but this remains speculative. A new transition is likely to be the usage of hydrogen, mainly for fuel cells powering vehicles, small energy generators and portable devices, (Schnepf, 2004).

Solar energy technology is very important tool which can lowers worldwide carbon emissions. The cost of solar energy technologies are rapid declining in the recent past years and it is showing potential for continuous declines in the near future. Currently, the installed capacity of solar energy projects in India is about $4.22 \mathrm{GW}$. India is planning to produce $100 \mathrm{GW}$ of solar power by 2022 .

\section{Materials and Methods}

The present study was conducted in Jaipur district of Rajasthan. There are total sixteen tehsils in Jaipur district of Rajasthan, out of which, two tehsils namely Chomuand Amber were selected on the basis of maximum number of installed of solar pump.Ten villages from each selected tehsils were selected randomly by using proportional allocation technique. One hundred twenty (120) farmers were selected from twenty selected village by using proportional allocation technique. Data were collected by investigator through personal interview technique with the help of developed structured schedule. Thereafter, data were tabulated and various statistical measures viz. per cent, mean, mean per cent scores, standard deviation, ranking and correlation were used to arrive at specific inference.

\section{Results and Discussion}

\section{Knowledge level of farmers about solar energy technology}

Under this section it was tried to find out the level of knowledge of farmers about solar energy technology and the level of knowledge of farmers about solar energy technology was assessed the knowledge of farmers about solar energy technology was divided into three categories based on the mean (37.641) and standard deviation (5.045) as presented below:

1. The farmers who obtained knowledge score below 32.51 were categorized as having low knowledge level about solar energy technology.

2. The farmers who obtained knowledge score from $32.51-43.72$ were categorized as having medium knowledge level. 
The farmers who obtained knowledge score above 43.72 were categorized under high knowledge level.

The data presented in table 1 show that majority of solar pump users i.e. 85 (70.83 per cent) belonged to middle level of knowledge, followed by high level of knowledge 19 (15.83 per cent). Whereas, only 13.34 per cent (16) solar pump users were belonged to the low level of knowledge

Aspect wise knowledge of farmers about solar energy technology

To get a clear picture of knowledge possessed by solar pump users, aspect wise knowledge of solar pump users was worked out. For this mean per cent scores for each aspect was calculated and ranks were accorded. The results of the same have been presented in table 2.

In overall, it has found that first rank is given to installation knowledge about solar pump (76.39 MPS) followed by technical knowledge (65.83 MPS), general knowledge (63.92 MPS), maintenance and repair knowledge (61.46 MPS), operational knowledge (61.30 MPS) and were ranked second, third, fourth and fifth, respectively. It indicate that solar pump users knew very well about installation, technical and general knowledge of solar pump.

Table.1 Distribution of respondents on the basis of level of knowledge about solar energy technology $n=120$

\begin{tabular}{|c|l|c|c|}
\hline S.No. & Knowledge Categories & Frequency & Percentage \\
\hline $\mathbf{1 .}$ & Low $(<32.51)$ & 16 & 13.34 \\
\hline $\mathbf{2 .}$ & Medium $(32.51-43.72)$ & 85 & 70.83 \\
\hline 3. & High $(>43.72)$ & 19 & 15.83 \\
\hline & Total & 120 & 100.00 \\
\hline
\end{tabular}

Mean $=38.11, \mathrm{SD}=5.60$

Table. 2 Extent of knowledge of farmers about solar energy technology $n=120$

\begin{tabular}{|c|l|c|c|}
\hline S.No. & Aspects/ Practices & MPS & RANK \\
\hline $\mathbf{1 .}$ & General knowledge & 63.92 & III \\
\hline $\mathbf{2 .}$ & Technical knowledge & 65.83 & II \\
\hline 3. & Installation knowledge & 76.39 & I \\
\hline $\mathbf{4 .}$ & Operational knowledge & 61.30 & V \\
\hline $\mathbf{5 .}$ & Maintenance and Repair knowledge & 61.46 & IV \\
\hline
\end{tabular}

MPS $=$ Mean Per cent Score

It was concluded from the finding that the majority (70.83 per cent) of respondents were having medium knowledge level followed by high (15.83 per cent) and low (13.34 per cent) knowledge category this might be due to the reason that about the extent of knowledge of individual aspects of solar energy technology, it was noted that extent of knowledge of 
'installation of solar pump' got the top rank. The second highest knowledge was found about the aspect like 'Technical knowledge' this might be due to the fact that it easy to use as no complicated technical know-how was required.

Thus, it could be concluded that the range of extent of knowledge was from 16 farmers belong to low $(<33)$ knowledge category whereas 85 and 19 farmers belong to medium (33 - 44) and high (>44) level of knowledge category. The respondents unanimously agreed to the fact that use of solar pump can be helpful in reducing environmental pollution, reducing irrigation cost, reducing dependency on electricity and raising economical condition of farmers. This might be due to the facts that there should be a proper repetitive educational campaign for popularizing the solar energy technology. An effective training package may definitely improve the knowledge level of the farmers.

\section{References}

Bunker, H.S.; Choudhary, L.R. and Lal, H. (2012): Knowledge level of beneficiary farmers about drip irrigation technology. Raj. J. Extn. Edu. 20: 117-120.

Chauhan, C.D.; Bhatt, M.R.; Parmar, V.S. and Charel, J.M. (2017): Knowledge of the farmers about low cost greenhouse technology. Int. J. Curr. Microbiol. App. Sci. 6(5): 97-102.

Kumar, A.; Godar A. K.; Shivrain, D. K. and Dhillon, A. (2015): Knowledge of farmers of Rohtak district regarding Photovoltaic Water Pumping System. Agri Bio Research Publishers.20(1): 106-109.

Musliha, N.; Borua, S.; Borua, R. and Deka, B. (2017): Knowledge Level of Farmers on Recommended Cultivation Practices of Off-season Vegetable Crops under Low Cost Polyhouse Technology in Assam. Asian Journal of Agricultural Extension, Economics and Sociology 21(4): 1-6.

Nasrin, M.; Borua, S.; Borua, R.andDeka, B. (2017): Knowledge Level of Farmers on Recommended Cultivation Practices of Off-season Vegetable Crops under Low Cost Polyhouse Technology in Assam. Asian J. Agril. Ext. Eco. and Sociology. 21(4): 1-6.

Singh, J. and Bhimawat, B.S. (2002): Assessment of knowledge of adopters and non-adopters towards drip irrigation technology. Raj. J. Ext. Edu. 10: 113116.

Us, A.; Florkowski, W. J. and Klepacka, A.M. (2014): Knowledge about renewable energy and household attitudes towards solar collector installation. Economic and Regional Studies. 7(4):86-98.

\section{How to cite this article:}

Neelesh Raghuwanshi, Jagdish Prasad Yadav, Ajit Kumar Ghoslya, Vikas Kumar and Sita Ram Bijarnia. 2020. Knowledge of Solar Energy Technology by the Farmers of Jaipur District in Rajasthan, India. Int.J.Curr.Microbiol.App.Sci. 9(03): 660-663.

doi: https://doi.org/10.20546/ijcmas.2020.903.079 